\title{
Vestígios, ruínas e fotografias... ou sobre alguns aconte- cimentos da imagem
}

RUBENS VENÂNCIO

Rubens Venâncio é fotógrafo, doutor em Artes (UFMG) e professor do curso de Artes Visuais da Universidade Regional do Cariri - URCA. Dedica-se à realização de trabalhos autorais, à pesquisa em fotografia documental, fotografia e práticas artísticas, à curadoria e ações de formação. Tem experiência na área de fotografia, teoria da imagem na arte, processos fotográficos antigos, antropologia - com ênfase memória, ruína e poéticas do esquecimento.

AFILIAÇÃO - Universidade Regional do Cariri (URCA) - Ceará - Brasil 


\section{- RESUMO}

Este artigo traz algumas reflexões sobre o trabalho com a memória em suas manifestações poéticas por meio da fotografia, a partir da criação do ensaio fotográfico "iminências", realizado em três locais do Ceará e composto por duas coleções: "lugar-ruína" e "lugar-memória". Para tanto, adotei a ideia de "memória-montagem" que, junto a um fazer conceitual e artístico, possibilitou o entrelaçamento entre memória, esquecimento e ruína.

\section{PALAVRAS-CHAVE}

Fotografia, memória, ruína, esquecimento.

\section{ABSTRACT}

I sought with this research to work with memory in its poetic manifestations through photography, from the creation of the photographic essay "imminences", realized in three places of Ceará and composed of two collections: "place-ruin" and "place-memory". For that, I adopted the idea of "memory-montage", as well as a conceptual and artistic doing that intertwined memory, forgetfulness and ruin.

- KEYWORDS

Photography, memory, ruin, forgetfulness. 


\section{O acontecimento-encontro}

Olhar para as ruínas é desejar a explosão, perceber o que fugiu ao continuum (BENJAMIN, 2007, p. 517).

Ao mapear particularidades e problemáticas nos distritos do Baixio das Palmeiras, Baixio do Múquem e Cococi (locais que serão mais a frente apresentados), identifiquei dois cenários que pautaram a investigação visual e foram assim nomeados: os dois primeiros começam a ser fotografados a partir da ideia de "iminência da desapropriação" e o terceiro a partir da ideia de "iminência do desaparecimento".

A coleção "lugar-memória" é composta por imagens criadas livremente sobre locais significativos apontados pelas narrativas dos moradores - seja por motivações afetivas, de memória, ou razões de outra ordem. Nessa coleção (em formato digital e realizada nos três espaços) procurei perceber pela via da criação fotográfico-imaginativa a relação com o espaço durante um cenário de desaparecimento e de imposição de desapropriações.

Já em "lugar-ruína" (feito com filme Polaroid grande formato) trabalhei no sentido de estabelecer memórias a partir das complexidades vividas pelos habitantes que estão dentro do contexto das iminências, mais especificamente, sobre os moradores dos Baixis que já se encontram nas novas residências após desapropriação e os que vivem em Cococi em meio aos destroços.

O Polaroid usado nessa pesquisa é um material que se encontra vencido e os que estão disponíveis para compra são vendidos, em sua grande maioria, em leilões na internet. Os químicos para revelação estão contidos dentro do envelope do filme e, devido a essa condição e somada à ação do tempo, a superfície fotográfica é afetada: ao puxar o lacre para abrir o filme e ver a foto, uma parte da imagem (ou toda ela) é deteriorada, tornando o resultado plástico sempre imprevisível: não sabemos qual parte e qual tamanho da imagem será corrompida.

Uma das questões norteadoras dessa investigação - que se deu entre 2013 e 2017 - foi como, com a narrativa fotográfica e as discussões propostas, surgirá uma tessitura que envolverá indivíduos, memória e ruínas? A criação dos "lugares" dependeu dessa questão. Mas que pessoas são essas, em qual cenário as experiências se deram?

Nos distritos rurais do Baixio do Múquem e no Baixio das Palmeiras moram centenas de famílias que vivem, em sua maioria, da agricultura familiar e partilham uma história e um intenso cotidiano de vivências. Ambos são distritos do município de Crato, região do Cariri cearense, e se encontram geograficamente entre suas principais cidades: Crato, Juazeiro do Norte e Barbalha. Atualmente as comunidades estão ameaçadas pelo projeto do Cinturão das Águas do Ceará (CAC), maior obra hídrica do Estado, que prevê a construção de um canal que, entre outros, trará água da Transposição das Águas do Rio São Francisco para o Ceará.

O discurso da segurança híbrida não foi suficiente para convencer os moradores do abandono de suas residências e da agriculta familiar baseada na sustentabilidade ambiental - estes, por sua vez, não sabem por onde exatamente passará o canal, quantas famílias serão desabrigadas, para onde vão e qual será impacto ambiental - friso a proximidade dos locais com a Chapada do Araripe. 
Nesse contexto não está em curso apenas a desestruturação territorial, mas outra de ordem humana: o desmonte de laços afetivos, alteração do modo de vida e, principalmente, a influência na memória dos moradores pela alteração/perda de vários vínculos, com suas memórias e identidades - momento em que a questão do esquecimento se põe. Algumas famílias já foram desapropriadas e outras aguardam as decisões do Estado, mas todas têm em comum a mesma preocupação: a iminência da desapropriação.

Cococi ("coco pequeno" em tupi-guarani), que já foi vila, distrito e cidade (extinta na década de 1960), está localizada no sertão dos Inhamuns, Ceará. Símbolo da colonização cearense, Cococi foi sede de uma das maiores sesmarias do Estado, desempenhando o papel de importante povoamento do Interior. Com suas histórias míticas e muito abalada pelo medo (a pistolagem e a violência contra os índios), o local já foi cantado em versos de Luiz Gonzaga.

Hoje, noticiada como abandonada, é um distrito de Parambu, a $50 \mathrm{~km}$ da sede do município. Na verdade um quase-local com oito moradores divididos em duas famílias que vivem da agricultura de subsistência, da venda de animais e outros serviços. Da antiga cidade, fora algumas casas que teimam em ficar de pé, ainda restam uma igreja (datada do século XVIII), o cemitério, uma parte da sede da prefeitura e o palacete da família Feitosa - família que fundou a então cidade.

Achada, Cococi perde-se nela mesma. Constituiu-se como um lugar que entrou em estado de latência, dormente, que parece não esperar mais nada além da passagem do tempo. Os silêncios dos destroços, ou os destroços causados pelos silêncios habitam esse distrito, bem como as ranhuras, fendas, espaços abertoesquecidos, onde é possível perceber as particularidades da relação entre as ruínas, as pessoas e a paisagem. Algo também é comum a esses poucos moradores: a iminência do desaparecimento.

\section{O acontecimento pulsa}

As dinâmicas de cada um desses espaços, as formas como eles se organizam enquanto espaço histórico, social e cultural lhes particularizam. Ao mesmo tempo, é essa realidade da dissolução de parte desses locais explorados pela imagem que os aproximou nessa investigação artística e funcionou como uma ponte entre a fotografia e a ruína.

O que se apresentou a mim como pesquisador e fotógrafo não foi apenas a situação de degradação ou abandono em que chegaram as edificações, mas como essas pessoas encontram-se envoltas nas iminências: por quanto tempo a cidade ficará de pé? Que memórias as pessoas levaram para as novas habitações? Como construir lembranças a partir da experiência do esquecimento?

O trabalho fotográfico trouxe à baila a questão da ruína e, assim, propus uma dobra: entre o contexto de ruínas ao qual as pessoas estavam submetidas e as da superfície fotográfica. A partir daí comecei a imaginá-las: de como essas iminências, ao anunciarem desapropriações e desaparecimentos, aparecem como elemento que detonariam uma visualidade.

Em "lugar-ruína", o intervalo do deslocamento entre uma casa e outra determinou essa coleção, onde o significado mais latente da ruína não estaria na casa 
abandonada, mas na atual, sem os antigos laços, uma representação edificada da ausência. Deslocamentos esses que foram compostos por pequenos entremeios: o esperar sair da casa após o aviso de desapropriação, a busca pela nova moradia, o mudar-se, o tempo para construir, o início do tempo do esquecimento, o adaptar-se ou não - para mim, todas são medidas temporais do abandono.
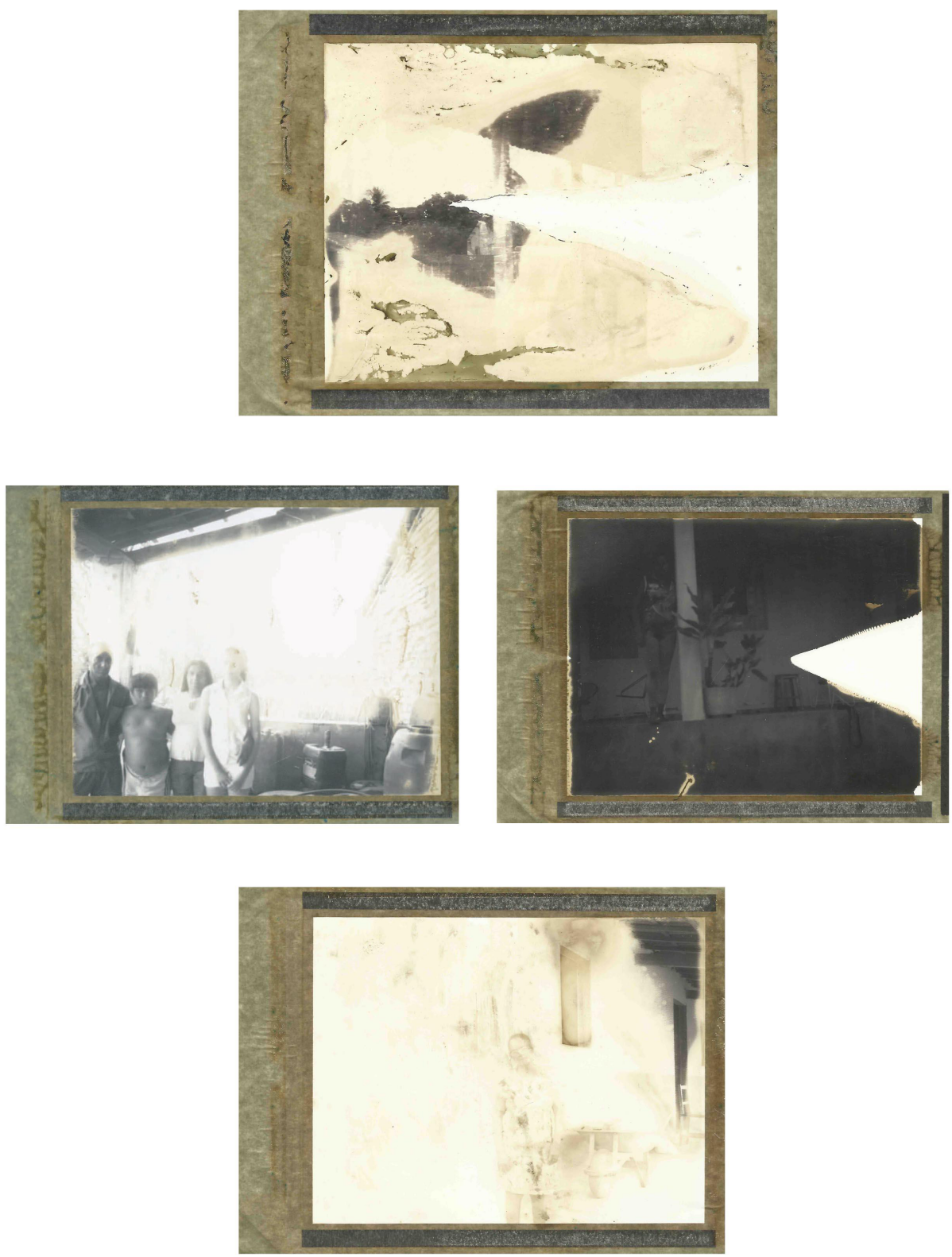

Figura 1. Fotografias da coleção "lugar-ruína" em Cococi e nos Baixis, 2013-2017. Fotografias do autor. 
Figura 2. Fotografias da coleção "lugar-memória" em Cococi e nos Baixis, 2013-2017. Fotografias do autor.
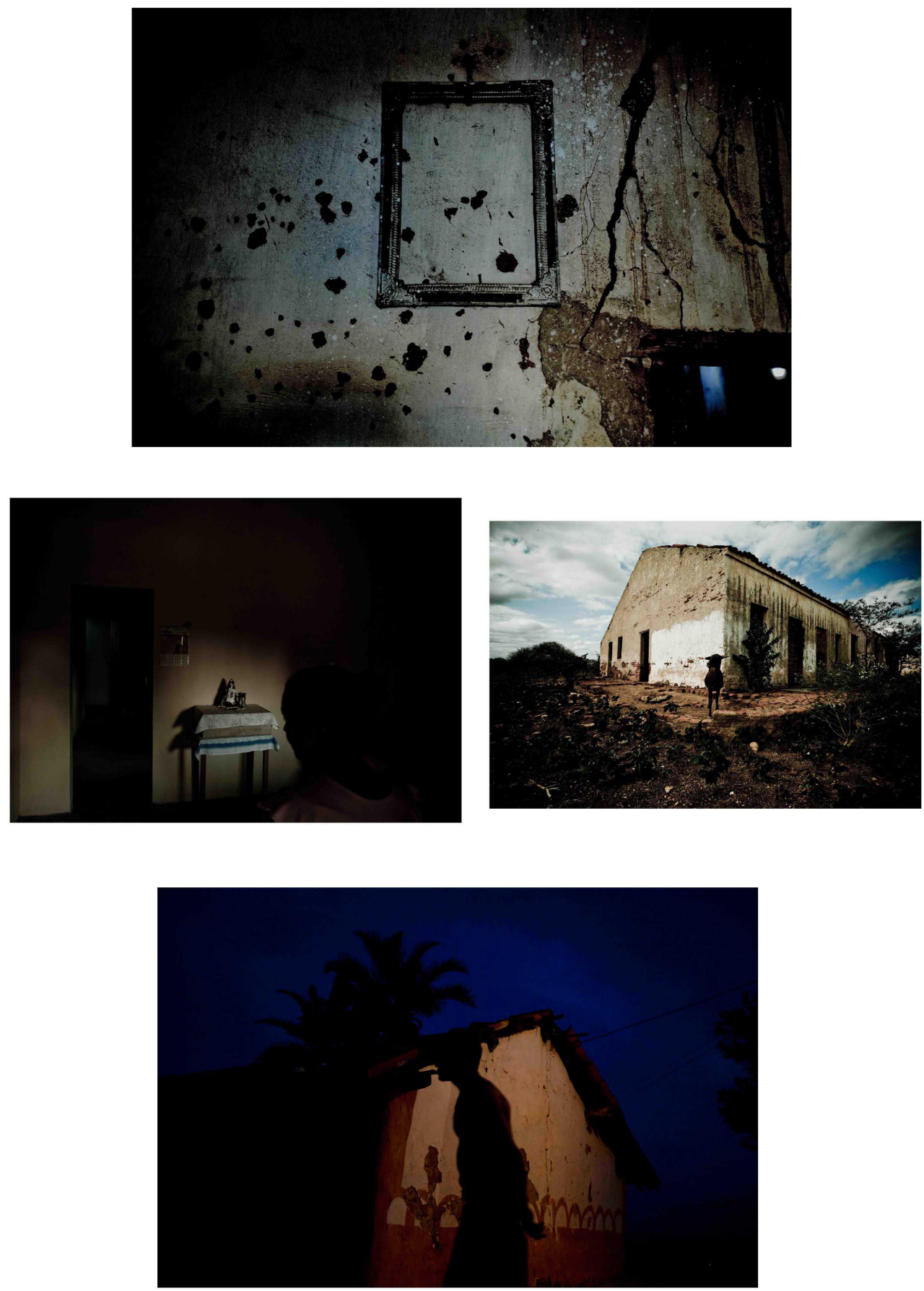
No caso de Cococi a medida do intervalo é o tempo estendido que consome a cidade e que também me leva à pergunta: até quando os moradores terão as casas em que residem? Ou ainda: porque as pessoas passam e as ruínas permanecem? Em ambos, essas esperas caracterizaram o tempo das iminências. As fotos (Figura 1 e 2) são formadas pelas imagens das pessoas e não dos locais desmoronando e nem das marcas deixadas no chão e na paisagem - tais situações estão no "lugar-memória".

Ao mesmo tempo, algumas fotos, por uma sintaxe da ruína trabalhada aqui pela imagem fotográfica, apontam para essas marcas: elas são a ação do tempo nos distritos, sumiu, mas tem restos, segura o olhar, fez pensar as mudanças. Sumiu, mas está lá, onde sumir parece ser da ordem do figurativo. Os borrões nas fotos em "lugar-ruína" são as iminências dispostas no enquadramento retangular, limites levemente ultrapassados quando as bordas misturam-se e fazem parte da imagem

O "lugar-memória" também prescindiu de uma narrativa lacunar, que precisou do intervalo, por situar-se entre o tempo que escuto as pessoas e fotografo; que precisou considerar as durações individuais dos moradores, na forma como cada um construiu suas expectativas e anseios. Muitas vezes voltava dias depois das entrevistas e vagueava pelos locais em busca de imagens inspiradas pelos relatos. Em outros, ia com os moradores pedindo que me indicassem lugares, o que me permitia voltar para fotografar.

Acompanhei as iminências e as ruínas, ano após ano, chuva após chuva, e veio as primeiras impressões: a iminência quando se concretizava ganhava a forma da ruína, deixava de ser da ordem do porvir para ser da ordem do acontecido. Uma alternância entre esses dois estados é percebida na vivência dos habitantes (seria essa uma dinâmica?): quando as ruínas crescem as iminências diminuem?

Em Cococi, Antônio e Ana (optei por usar apenas o primeiro nome dos moradores aqui citados) continuam em meio as suas atividades: o primeiro continua com as obrigações de vaqueiro, cuidando da terra e de sua casa. A segunda cuidando da casa, dos animais e outros afazeres além de atuar na atividade de zelar pela igreja - junto com Clemilde. Não à toa, é somente em suas casas e na igreja, em que todos desempenham atividades por ocorrer uma missa por mês, que eles conseguem manter alguns espaços conservados.

Em uma das fotos na Figura 1, cuja família está reunida, me vem à tona algumas impressões a partir dessas afazeres: todos mantêm seu cotidiano minimamente estruturado em sintonia com as possibilidades do lugar, ou seja, convivendo com a ruína. Esse existir está relacionado com um tipo de iminência que não é total, não pode ser previsto seu desfecho, porém se faz presente. A observação desse paradoxo - da ausência e presença - é importante porque ele se estabelece como uma caracterização do arruinamento, onde a ruína existe, mas não exclui o viver, e este se realiza em seus contextos de existência.

Ao considerar o exposto sobre os moradores de Cococi, lembro que eles, volta e meia, parecem esquecer que o lugar está sumindo. Ao mesmo tempo em que estão próximos às ruínas quando olham para a casa que caiu ao lado das suas, eles acompanham Diogo ir à escola todos os dias, ou recebem os vizinhos da fazenda ao lado que os visitam para atualizar as notícias. Clemilde, quando deixa cla- 
ro que almeja terminar seus dias em Cococi, parece não atentar para o que ocorre ao redor, talvez não considere que a cidade pode vir a cair antes dela, que os moradores da outra casa podem mudar-se. É como se houvesse uma suspensão da ruína.

Ao viverem um esquecimento forçado, os moradores dos locais lembram a partir do que desaparece. Seus relatos são uma expressão de suas vivências sob o impacto e o convívio com as iminências, foram fundados por elas, não no sentido de terem uma origem, mas pensando a partir de quais contextos esses relatos vieram à tona. Assim a iminência existe, ela atua com e nas ruínas mais antigas de Cococi. Atua, como também no caso dos dois Baixis, no ato de recordar dos habitantes quando despertam suas memórias, bem como na fotografia que abriga o acontecimento - no caso, o que está sumindo pelas suas características físicas e químicas e pela minha atuação em não criar uma situação mínima de preservação.

A iminência na fotografia faz-se presente no filme quando a imagem é fixada em um suporte que já se encontra em deterioração, e quando essa mesma imagem é alterada pelo aumento da deterioração da superfície. No primeiro caso há uma alusão ao fato da iminência estar presente na vida dos moradores (imagem fixada), no outro há a sua instabilidade que não se deixar prever quanto ao seu aumento (em que direção ou tamanho a imagem será afetada).

Vejo o gesto fotográfico trabalhando essas memórias enquanto um acontecimento criado para/pela a imagem ao ordenar essas lembranças em nível narrativovisual, onde as coleções representam a concretização do esquecimento em memórias performadas pela poética fotográfica. Gesto que também atuou levando em consideração que "(...) pra recordar é preciso imaginar" (DIDI-HUBERMAN, p. 97, 2012).

Tal qual as ruínas, as imagens que compõem o "lugar-ruína" existem como ambiguidades, se concretizam em algo e ao mesmo tempo deixam visualizar uma falta: o está sendo perdido - já que tantos relatos foram pautados pelo esquecimento. Já em "lugar-memória", mesmo a ruína não estando em sua superfície, de forma material, ela está nas imagens e nos depoimentos - como no caso da última foto da Figura 2 em que Zé, agricultor dos Baixis, levou-me a um local que não sabe se será atingido pela obra, mas que já manifesta uma preocupação com o lugar, como um sentimento de ausência que se anuncia.

Em Benjamim (2007), Ricoeur (1997), Simmel (1998), a ruína tem uma nuance em comum: ela aponta para algo fora dela, por isso em sua base conceitual ela pode ser interpretada enquanto pista, abertura, representando algo que não existe. Esse "fora dela" desdobrou-se, para mim, no seguinte sentido: nas narrativas imaginadas construídas a partir dos relatos que, por sua vez, funcionaram como pistas que a fotografia perseguiu.

A discussão sobre a ruína nesse trabalho se deu no sentido de ser um vetor das memórias e da forma como somos tocados por elas: ela levou a pensar no passado, a sentir saudade, a lamentar o futuro, ela comunicou, portanto a ideia de ruína não se aproxima da de "escombro", de restos mudos. A importância do reconhecimento da ruína que se dá pelo trabalho narrativo é o que a distancia dos escombros: 
A ruína é assim um testemunho do passado sem funcionalidade no presente, mas que pelo estudo, pela reconstrução, torna possível reapresentar o sentido da história. Pelo contrário, o escombro é o testemunho da interrupção brutal da história e, como tal, a reconstrução que dele se pode reelaborar sofrerá sempre da impossibilidade de completude, pela suspensão de sentido que ele (escombro) exibe. (VECCHI; RIBEIRO, 2012, p. 97).

Nesse sentido, a ruína enquanto vestígio, ou que deixa vestígios, é um vetor para discorrer sobre o aparecimento - Benjamim afirmava: "O vestígio é o aparecimento de uma proximidade, ainda que possa ser longínquo o que ele deixou atrás de si" (2007, p. 490). Pensando na narrativa construída pela criação artística, há uma função de conhecimento que se desenvolve no funcionamento do vestígio. A ausência não é total, ela existe na medida do que restou e no que podemos erguer de formulação teórica e artística a partir desses vestígios. Tal qual a presença, não é total porque existe enquanto algo que falta e, por mais opostos que pareçam, são sentidos que podem existir conjuntamente.

As fragilidades que permearam a memória das pessoas, o contexto enunciativo (desapropriação e desaparecimento) e o processo de captura de imagem, são os lugares onde se inscreveu meu processo de trabalho e se estabeleceram os testemunhos: instáveis e frágeis, mas que deixaram uma abertura, no caso: "De pensar que é nas instabilidades do filme que reside a potência artística" (FALCI, 2013).

Chama-se a lembrança de uma imagem do passado (RICOEUR, 2007) e não o próprio passado, entre outros, porque o passado está ausente e distante do presente-acontecimento onde se instala a possibilidade da recordação. As coleções foram construídas a partir das lembranças que surgiram com a situação de esquecimento na qual estão inseridos os moradores. Tendo em vista a vivência em lugares onde existem a desapropriação e o desaparecimento, o recordar tornar-se um operador do da memória: dele sobressai a relação com o espaço, com o modo de vida, com a fotografia.

O ensaio, ao trazer em sua visualidade o desaparecimento, preparou determinado campo para entender um viver que se faz dentro de um esquecimento forçado, que o indivíduo lembra a partir do que desaparece, que as coleções podem ser arcabouços de lembranças que se retroalimentaram pela ausência. Onde pode ser visto tanto uma memória sendo inscrita fora das pessoas que recordam, como também a memória manifesta na fotografia (que visualmente as ordenou em uma superfície) e pela fotografia (como objeto tecnológico capaz de agenciar discursos). Em ambos destaco uma imagem que realça o trabalho com a memória, ouvindo-a, como uma escuta da alteridade, e inscrevendo-a em uma temporalidade particular:

A narração inscreve a experiência numa temporalidade que não é a de seu acontecer (ameaçado desde seu próprio começo pela passagem do tempo e pelo irrepetível), mas a de sua lembrança. A narração também funda uma temporalidade, que a cada repetição e a cada variante torna a se atualizar. (SARLO, 2007, p. 25). 
Enfim, as coleções representam a escolha dos meus procedimentos de trabalhos com os materiais, suportes e linguagem, com a participação das pessoas por meio de seus relatos e a gentil doação de seu tempo, problemas e intimidades a narrativa visual comportou todos essas instâncias no momento em que as vinculou enquanto imagem capaz de contar histórias, de produzir sentidos e inteligibilidades.

Entretanto, como sincronizar o que para mim foram roteiros poéticos? Vide: os percursos dos moradores pelos caminhos de suas memórias; os percursos da fotografia em uma experiência visual de criação; e os meus percursos como fotógrafo. Aqui entra a "memória-montagem".

Alicerçado na interação com os moradores fui escutando os relatos e criando meus caminhos como fotógrafo à procura de fotografias que não explicassem, mas que me levassem a inscrever em/com imagens todas aquelas multiplicidade de vivências e o cenário de ruínas. Assim, a fotografia, os testemunhos, a edição do ensaio, todas as etapas da construção visual, concretizaram esse que foi um gesto da imagem ou uma imagem-acontecimento.

Didi-Huberman (2012), com o que chamou de "imagem-montagem" ou "imagem-mentira", debateu sobre um saber que nasce fundamentado na interpretação e associação de imagens dispostos em tempos distintos. Assim ele explana as "montagens imaginárias" (2012, p. 160):

(...) A legibilidade dessas imagens - e, por conseguinte, o seu eventual papel num conhecimento do processo em questão - só pode ser construída quando estas estabelecem ressonâncias ou diferenças com outras fontes, imagens ou testemunhos. O valor de conhecimento nunca seria intrínseco a uma única imagem, tal como a imaginação não consiste em imiscuir-se passivamente numa só imagem. Trata-se, ao contrário, de pôr o múltiplo em movimento, de não isolar nada, de fazer surgir os hiatos e as analogias, as indeterminações e as sobredeterminações em jogo nas imagens. (DIDI-HUBERMAN, 2012, p. 155).

A "memória-montagem" permitiu-me elaborar uma narrativa sobre ruínas pela fotografia, relatos e pelo texto - vide as coleções, os testemunhos e a discussão teórica - ao funcionar como uma maneira de ordenar vozes, escritas, imagens, e ao exibir o que está nas entrelinhas, o que está por escapar ao olhar, o que surgiu pelo trabalho imaginativo da memória.

As coleções foram um instrumento e efeito da montagem ao criar uma visualidade ao mesmo tempo em que as imagens também giraram em torno dos testemunhos. Assim, a memória surgiu como fenômeno pelo trabalho poético da imagem - ou "(...) as proposições de experimentação da memória que as imagens podem evocar no presente. A imagem poética exercita o confronto com a perda e é capaz de reescrever uma nova memória" (KLATAU FILHO, 2012, p. 22).

O procedimento da "memória-montagem" significou a elaboração de um conhecimento pautado pela narrativa fotográfica e pela narrativa de memória dos interlocutores, no caso, pelos testemunhos que versaram sobre a relação com os 
lugares vividos e imaginados, os laços de afetividade, a relação com a água e, também, sobre o que é recordar baseado em um cenário de esquecimento e instabilidades.

Acredito que uma forma de pensar a relação entre as duas narrativas no ensaio "iminências", seja que ambas não explicam, não descrevem, mas imaginam, convidam, sugerem, são uma evidência sensorial. E que nas fotografias estão o encontro das minhas percepções e a dos moradores, sendo o ensaio uma forma de compartilhá-las.

Com essas narrativas foi possível aproximar a questão da ruína com a de acontecimento, considerando o que ficou para trás a partir da identificação do acontecimento e o que começou a ser produzido a partir de seu impacto, vindo a singularizar uma série de coisas: "Talvez possamos equivaler sempre Acontecimento e Singularidade" (SILVA, 2010, p. 20). Também consider que os significados elaborados pelo acontecimento (DELEUZE, 1982) - ele produz, vibra, reconfigura, singulariza etc -, podem ser vistos nas ações dos indivíduos ou presentes na imagem, estão relacionadas aos tipos de experiências que nós vivemos.

Os três locais instigaram-me à reflexão na busca por uma visualidade que particularizasse a minha inserção. Posso dizer que, de certo modo, esses acontecimentos também me perturbaram, mas como "(...) acontecimentos poeticamente transfigurados pela memória, apreendidos, como imagem (...)" (LISSOVSKY, 2005, p. 141). A fotografia ao expressar um visível que comportasse essas movimentações, pôde se tornar um acontecimento, ela é a expressão dessa experiência como singular, visual. Porque o acontecimento, com sua estreita ligação com o cotidiano, é da ordem da invasão, ele surge, mistura-se, traz algo novo - e invasão não significa necessariamente romper, mas inserir-se com outra dinâmica.

\section{O acontecimento produz}

Há três acenos que representaram os fluxos desse trabalho, do ir e vir entre o pensar e a experimentação: o tornar imagem, o deslizar para dentro da imagem e a imagem-heurística. A memória-montagem foi um dispositivo que funcionou da seguinte maneira em relação a estes acenos: representou a criação da imagem no momento em que os Baixis e Cococi despontam como uma imagem-acontecimento; fez-me deslizar para dentro da imagem com a feitura do ensaio fotográfico; até o momento em que a imagem detonou as possibilidades de interpretação e conhecimento ao entrelaçar ruínas, esquecimentos e iminências, onde destaquei uma "capacidade de imaginação narrativa" (GINZBURG, 2012, p. 120).

A opção por trabalhar com o formato "coleções" está relacionada às posições desempenhadas pela fotografia, quando ela fundou contextos de interpretação para o que está sendo investigado. A partir desse momento, a fotografia presta-se não só a interpretar os testemunhos, mas a desdobrá-los em formas visuais, permitindo-me trabalhar com formatos diferentes, com preto e branco e cor e, principalmente, pela sua organização estar em sintonia com as problemáticas abordadas.

O que pediu o ensaio? O desejo de narrar, de alongar a superfície, a tensão com a palavra, a transformação de ideias em imagens. Nas coleções estão inscritos Cococi e os Baixis, em sentido material e discursivo. $O$ que foi revelado é o que res- 
tou dos espaços; a área da imagem ausente é o que passou - pessoas, acontecimentos -, é o traço do esquecimento, é o pressentimento de algo: o espaço vazio é a ausência percebida enquanto intuição, como o cego que não conhece pelos olhos.

O acontecimento não descreve, ele produz. Partindo desse pressuposto, verifico duas situações que entrelaçaram aqui a existência da fotografia: ela teceu experiências com a criação dos "lugares" e, ao mesmo tempo, proporcionou o encontro entre os lugares. Ela tornou-se acontecimento no momento em que Cococi e os Baixis revelaram-se inteligíveis pelo trabalho das coleções. O acontecimento também pulsa:

O acontecimento é uma vibração, com uma infinidade de harmónicos ou de sub-múltiplos, tal uma onda sonora, uma onda luminosa, ou mesmo uma parte de espaço cada vez mais pequeno ao longo de uma duração cada vez mais pequena. Porque o espaço e o tempo são, não limites, mas coordenadas abstractas de todas as séries, elas mesmas em extensão. (DELEUZE apud SILVA, 2010, p. 30).

De uma forma ou de outra a fotografia pulsou: os lugares de investigação e os acontecimentos estão conectados pelas experiências, sendo a fotografia uma proposição de organização delas de ordem visual, estética e sensível. Criar o "lugarruína" e o "lugar-memória" foi uma forma de ordenação dos acontecimentos ao mesmo tempo em que a fotografia tornou-se um: produziu o encontro, apagou demarcações físicas, potencializou a criação de visualidades e tornou-se um gesto do esquecimento e da memória. As coleções foram um acontecimento do olhar, onde escolhas, fugacidades e lacunas se inscreveram e deslizaram pelas superfícies.

A concepção das coleções, além de levaram em conta questões poéticas e formais, se estabeleceram como plataformas de observação e criação ao interpretar os acontecimentos à luz da experiência fotográfica. Representaram a fotografia manuseando o esquecimento e a memória: imaginando o presente em busca de efeitos de passado e projeções para o futuro; ela fugiu da simplicidade do armazenar, do inventariar as memórias - no máximo ela inventaria o ato criativo que perpassou o fazer fotográfico. Enquanto uns acreditam que a fotografia representa o ausente, aqui ela constrói a partir do ausente.

Na perspectiva de construção fotográfico adotada, o registro tornou-se uma materialidade do vestígio e não do real. Vestígios como os rastros de nossas intenções, do dispositivo técnico, dos materiais que optamos por trabalhar. O gesto favoreceu-me pensar em termos de um "isto está acontecendo", ou "isto está se anunciando" e desenvolver um posicionamento diante da imagem que privilegia os processos, as problemáticas e os eventos (ROUILLÉ, 2009, p. 163).

Ver o que imaginava, imaginar pela ausência, ser afetado pela imagem, ter saudades. $O$ ensaio versou sobre isso e também sobre se posicionar contra o que se esvai, sobre estar diante do apagamento com o aumento das ruínas - ele foi o tom, o som, o "ver" e, também, foi um discurso sobre recordar o esquecimento, de tornar-se objeto estético.

A superfície, ao transparecer o que emergiu, envolveu experiências de imer- 
são: os vestígios, a minha passagem, os percursos realizados, os protocolos de criação, questionamentos conceituais voltados para a imagem, além de delicadas questões. Ela foi riscada pelos acontecimentos da pesquisa. A superfície é como uma dimensão de inscrição - tal qual a ruína e a memória -, bem como a fotografia, apropriando-se do que Deleuze afirmou sobre a filosofia, como uma arte da superfície: "Se você não constituir uma superfície de inscrição, o não-oculto permanecerá não-visível” (DELEUZE, 1992, p. 109).

Acompanhei os "lugares" e os esquecimentos transformando-se em imagem e permeado pela instabilidade: do ambiente sob iminências, do filme fotográfico; do lembrar a partir do que some, de escutar sobre o lugar arruinado na fala dos moradores; a partir do digital, como luz em pixel, memória em pixel, a ruína baseada na liquidez que é a formação numérica da imagem digital - ela, que carrega o ritmo acelerado da contemporaneidade, fez fluir vivências ditadas pelo ritmo da experiência.

Entendo a memória como um dispositivo por estar situada em um local de relações e forças, entre um conjunto de discursos e enunciados que nos provocam a pensar quais as suas particularidades na atualidade. Memória e esquecimento têm seus desafios sendo colocados pelas tecnologias e suas formas de registro, pelas redes sócio-técnicas, pelas formas como são difundidos, pela ampliação e consideração de outros tipos de documentos. Outras potências estão sendo exploradas e que somadas a outras possibilidades, misturam campos epistemológicos e delineiam uma expressão mais contemporânea da memória

Gostaria de encerrar esse artigo com algumas palavras acerca de duas fotos.

Momentaneamente, para efeito de análise, não li "A câmara clara" (BARTHES, 1984) buscando caracterizações ontológicas da imagem fotográfica, mas sobre a memória e a capacidade de afeção das imagens. O autor, ao analisar a foto de sua falecida mãe, centra o debate na ausência - essa foto nem mesmo é exibida no livro - e fala de um lugar que não existe mais, de um lugar do esquecimento, de um rastro documental. É esse lugar invisível que, justamente, traz a forma de como ele é afetado por essa memória, por caminhos afetivos.

Se o livro é como o seu ato de recordar, e a imagem é o local da rememoração, Barthes não só transforma a fotografia em um lugar do imaginar, mas estende esse estatuto ao que não existe mais ou ao que só passa a existir como rastro afetivo. Soulages assim comentou: "E a fotografia - Barthes expressou bem o fato - é essa arte que, ao mesmo tempo, se coloca como aquilo que pode vencer o esquecimento e se impõe como aquilo através do qual se dá o esquecimento (...)" (2010, p. 196).

A foto da moldura vazia na parede (a primeira da Figura 2) pode ser uma síntese das coleções e, porque não, dos percursos da fotografia: ela enquadra sem enquadrar; tem um presença arrebatadora no vácuo de seu espaço interno. Não enquadra porque as pessoas e os temas abordados são da ordem do fugidio, escapam-Ihe, a enunciação da moldura não os comporta. Enquanto veredas, as ranhuras dentro da moldura são direções que começam fora dela ou partem dela a se encontrarem em pontos escondidos, até não vistos na fotografia e se dispersam novamente. São como janelas, cobogós, venezianas, claraboias por onde passa luz, a abrir e fechar com os ventos soprados - difíceis em vários meses do ano cearense. 
Os materiais que compõem a moldura trazem forte o nosso imaginário das fotos antigas, as salas nos rincões do sertão - afinal, era o que se representava na parede das famílias como objetos de grande valor afetivo, até de culto. Contudo, essa madeira antiga, com ferros nas laterais e canaletas, é também a atualidade, a contemporaneidade de gestos da fotografia dados pelos traços de meu olhar: ao priorizar a interação, ao trazer os vestígios para o processo fotográfico.

A moldura é o ponto central de uma imagem maior, ela é parte da parede onde o tempo nela se desenha. Não a vejo como obra, mas a observo como um objeto por inteiro, ela é o resto da casa não vista, ela depõe sobre/com Cococi e os Baixis. Se fosse em busca de uma forma para as narrativas, elas seriam as marcas nas paredes a funcionar como sinais; também as rachaduras como trilhas; o reboco que cai a mostrar que o tempo não pede passagem; o caminho dos cupins são desenhos dos acessos pelos quais percorri. A luz a espreitar-se no cantinho azul...não sei para onde leva.

\section{REFERÊNCIAS}

BARTHES, Roland. A Câmara clara: notas sobre a fotografia. Rio de Janeiro: Nova Fronteira, 1984.

BENJAMIN, Walter. Passagens. Belo Horizonte: Editora UFMG; São Paulo: Impressa Oficial do Estado de São Paulo, 2007.

https://doi.org/10.17851/2359-0076.27.37.223-226

DELEUZE, Gilles. Conversações: 1972-1990. São Paulo: Ed. 34, 1992.

Lógica do sentido. São Paulo: Perspectiva, 1982

DIDI-HUBERMAN, Georges. Imagens apesar de tudo. Lisboa: KKYM, 2012.

FALCI, Carlos Henrique Rezende; SOUZA, Leonardo. A potência poética da individuação em performances audiovisuais criadas com objetos-sujeitos tecnológicos. In: Encontro Nacional de Pesquisadores em Artes Plásticas, 22., 2013, Bélem. Anais...Bélem: ANPAP/PPGARTES/ICA/UFPA, 2013. p. 3546-3561.

GINZBURG, Jaime. A interpretação do rastro em Walter Benjamin. In: SEDLMAYER, Sabrina; GINZBURG; Jaime. Walter Benjamin: rastro, aura e história. Belo Horizonte: Ed. UFMG, 2012.

https://doi.org/10.1590/s1517-106x2013000100016

KLATAU FILHO, Mariano. Prêmio Diário Contemporâneo de Fotografia: memória das imagens. Bélem: Diário do Pará, 2012.

LISSOVSKY, Maurício. A memória e as condições poéticas do acontecimento. In: DODEBEI, Vera; GONDAR, Jô (orgs). O que é memória social? Rio de Janeiro: Contra Capa Livraria, 2005. 
RICOEUR, Paul. Tempo e narrativa. Vol. 3. Campinas: Papirus, 1997. RICOEUR, Paul. A memória, a história, o esquecimento. Campinas: Ed. da Unicamp,

2007.

SARLO, Beatriz. Tempo passado: cultura da memória e guinada subjetiva. São Paulo: Cia das Letras; Belo Horizonte: UFMG, 2007.

https://doi.org/10.18542/rmi.v4i5.2797

SILVA, Fernando Machado. Poiética do acontecimento: Deleuze e Serres. Covilhã: Coleção Artigos LusoSofia, 2010.

SIMMEL, Georg. A ruína. In: Simmel e a modernidade. SOUZA, Jessé e ÖELZE, Berthold. Brasília: UnB. 1998.

Recebido em 15/06/2018 - Aprovado em 02/04/2019

Como citar:

Venâncio, R. (2019) Vestígios, ruínas e fotografias... ou sobre alguns acontecimentos da imagem. OuvirOUver, 15(1), 142-156. https://doi.org/10.14393/OUV24-v15n1a2019-10

(c) (7) (-) A revista ouvirOUver está licenciada com uma Licença Creative Commons Atribuição-NãoComercial 4.0 Internacional. 